TITLE:

\title{
Dipole Moment and End-to-End Distance of Syndiotactic Vinyl Polymer(Abstract_要旨)
}

$\operatorname{AUTHOR}(S)$ :

Mori, Tsugio

CITATION:

Mori, Tsugio. Dipole Moment and End-to-End Distance of Syndiotactic Vinyl Polymer. 京都大学, 1965, 理学博士

ISSUE DATE:

1965-03-23

URL:

http://hdl.handle.net/2433/211528

RIGHT: 


\section{[ 58 】}

\section{氏 名}

学位の種 類 学位記番号 学位授与の日付 学位授与の要件 学位諭文題目

論文調査委員

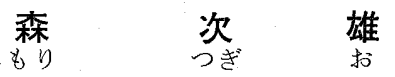

理 学 博 士

論 理 博 第 93 号

昭 和 40 年 3 月 23 日

学 位 規 則第 5 条第 2 項該当

\section{Dipole Moment and End-to-End Distance of Syndio- tactic Vinyl Polymer}

(シンジオタクチック型ビニール系高分子の双極子モーメントと 両端間距離との関係）

(主 査)

教授小林稔教授富田和久教授松原武生

\section{論 交内容 の 要旨}

溶液中の鎖状高分子の形や広がりに関する統計的な性質を調べることは，高分子化学工学の力からの䒠 際的要求屯あって，古くから研究されてきている。一般に問題となる鎖状高分子の主鎖は $\mathrm{C}-\mathrm{C}$ 結合があ る結合角で長くつながったあのであるが，てれらのCーC 結合はその結合のまわりに回転できるために溶 液中ではその温度や溶媒の条件に応じてあるまとまった形をとることができる。非結晶性高分子ではこの ような結合のまわりの内部回転が比較的自由であるため，数学的には一種のランダム・ウォークの問題之 して計算でき，掞もに離れた要素間の相互作用が興味のある問題になり，いわゆる排除体積効果の問題と して発展し，多くの成果が得られている。しかし，結晶性高分子とくにアイソタクチックおよびシンジオ タクチックなどの立体規則性高分子では内部回転のポテンシャルに規則性があり，各要素の回転が独立で なく相関があるため，分子全体としての形や広がりを統計的に計算するてとが困難になる。そのため立体 規則性高分子に対する理論的研究は比較的遅れているのが現状である。

$\mathrm{C}$ 一 C 結合の内部回転に対する，たとえば水島型ポテンシャルを想定して，各要素の回転が独立である とした場合に，分子の両端間距離の 2 乗平均に対する理論的計算としてはアイリングの式を一般化した岡 の式が西る。しかし，立体規則性高分子の特性を解朋するためには内部回転の相関を考慮に入れなければ ならない。著者は，その一つの試みとして主鎖のC一C絬合を隣接対の二つずつの組みにわけて，その隣 接刘の相関ポテンシャルを導入し，それを用いてつぎつぎの絬合の状態を決めるマトリックスを計算し， いわゆる行列の方法によって両端間距離の 2 乗平均を求兴式を導出するととに成功した。

主論文ではシンジオタクチックービニールポリマーに対する相関ポテンシャルを用いて上記の与法によ り両端間距離の 2 乗平均の計算を行なっているが，その結果孔今まで求められているものとしては最も一 般的な内容をあつものであって，その特別の湯合として Birshtein-Ptitsynの式，さらに岡の式が導出 される。この計算はマルコフ鎖の範囲の理論であるため両端間距離の 2 乗平均 $<R^{2}>$ は要素の数 $N$ に此例 するが，排除体積効果を考慮すれば $N^{1+\nu}(0<\nu<1)$ に比例することがわかっている。著者はフローリー 
の半経験的理論を併用して，さらにての効果を調べ, シンジオタクチックの場合にはレが 0 に近いととを 主張している。てれ怡若論文で示されているアイソタクチックの場合のレ 0.25 という絬果と比較して 興味のあるととである。

主論文で得られている他の一つの重要な結果は, 同様な計算によってシンジオタクチック型の場合の分 子の双極子モーメントを計算し分子の広がりと双極子モーメントとの関係を調べているととである。その 結果によるとシンジオタクチック型で法両端間距離が大きくなると双極子モーメントが小さくなり，アイ ソタクチック型にくらべて一般に双極子モーメントは小さくなる傾向が示されている。と机と充分比較で きるだけ実験のデーターは揃っていないが，現在得られている測定值は同じ傾问を示していることがわか っている。

参考論文はすべて主論文同様立体規則性高分子の広がりと双極子モーメントの理論的研究に関係したも ので，とくにアイソタクチック型のビニール・ポリマーに対して主論文と同様の方法を用いて計算を行な ったものである。すなわち，アイソタクチックの場合の両端間距離の 2 乗平均の一般式, 排除体積効果, 双極子モーメントが計算されている。したがって，主論文と参考論文を合わせて，立体規則性高分子の内 部回転の相関を取り入れたマトリックスの方法による広がりと双極子モーメントの理論的研究として一連 のまとまった研究になっている。

\section{論 文審查の 結 果の 要旨}

立体規則性高分子の溶液中での形や広がり，さらには分子全体としての双極子モーメントなどに対する 理論的研究は，分子の内部回転に相関があるため取り扱いが複雑で，比较的最近にいたるまで十分解明さ れていなかった。すなわち，鎖状高分子の主鎖を形成しているC一C 結合のまわりの内部回転がそれぞれ 独立に行なわれる場合には，問題は比較的簡単で，たとえば分子の雨端間距離の 2 乗平均 $<R^{2}>$ に対し てはアイリングの式やそれを一般化した岡の式等が知られている。とてろが，アイソタクチックあるいは シンジオタクチックービニールポリマーなどのような場合にはつぎつぎのC一C結合の回転の間に強い相 関があって，との相関を考慮に入れなりればその特性を解明するととはできない。著者はこの相関を取り 入れる一つの試みとして主鎖の C一C 結合の隣接対の二つずつを組にわけて，その隣接対の相関ポテンシ ャルを考慮して，つぎつぎのC一C 結合の状態を決めるマトリックスを作り，いわゆるマトリックスの方 法によって両端間距離の 2 乗平均を求める一般的な式を導出している。

主論文ではシンジオタクチックービニールポリマーに対する相関ポテンシャルを用いてマトリックスを 計算し，それから両端間距離の2 乗平均の計算を行なっているが，その結果は今まで求められているもの の中では最も一般的な内容をむったものである。すなわち，乙の一般的な式の特別な場合として Birshtein-Ptitsyn の式が，さらに回転ポテンシャルの対称性と独立性を仮定すれば直ちに簡监化された岡 の式が䆃出できる。したがって，ての結果は単にビニール系ポリマーに限らず他の立体規則性高分子につ いても，その回転ポテンシャルの特性を入れてやれば直ちに使える一般的有用な結果を与えている。

上記の両端間距離の 2 乗平均 $<R^{2}>$ の計算はマルコフ鎖の範囲の理諭になっているため $<R^{2}>$ は鎖 の数 $N$ に比例する結果を与えているが，排除体樍効果を考慮に入れれば $N^{i+\nu}(0<\nu<1)$ に比例すること 
が知られている。著者は主論文において，フローリーの半経験的理論を併用するととによって，さらにて の効果を調べ，シンジオタクチック型の場合にはンが０に近いととを計算によって示している。乙れは参 考論文で計算されているアイソタクチック型の場合の值 $\nu \simeq 0.25$ という結果と比較して両型の空間的配位 の違いを示す一つの特性として興味のある結果であり，今後の理論的研究の対象として問題を提起してい るように思われる。

主論文で得られているもう一つの重要な結果は, 同様な計算によってシンジオタクチック型の場合の分 子全体としての双極子モーメントを計算し，それと分子の広がりとの関係を調べている。その結果による とシンジオタクチック型では両端間距離が大きくなると双極子モーメントが小さくなり，アイソタクチッ ク型に比べて一般に双極子モーメントが小さくなる傾向が示されている。とれらの結果と十分比較できる だけの実験データは現在そろっていないが，現在得られているデータは大体同じ傾向を示すととがわかっ ている。

参考論文はアイソタクチック型の場合に主論文と同じ方法によって, 両端間距離の 2 乗平均, 双極子モ 一メントなどを計算したもので，乙れらを合わせて立体規則性高分子の広がりと双極子モーメントに関す る理論的研究として一連のまとまった研究になっており，乙の方面の問題としては最む一般的な形式で取 り扱ったものとして優れた労作である。

要するに，著者森次雄は立体規則性高分子の広がりと双極子モーメントの統計的性質を詳しく研究し， この研究分野に種々の新しい知見を加え，寄与貢献するとてろ少なくない。主論文および参考論文を通 じ，著者が高分子物理学について豊富な知識と研究能力をむっているととを認めることができた。

よって, 本論文は理学博士の学位論文として価值があるものと認める。 